\title{
Detection of chlamydia and other bacteria in cervicitis.
}

\author{
Asmaa Z. Sheetawy, Zainalabideen A. Abdulla.
}

Department of Microbiology, College of Medicine, University of Mosul.

(Ann. Coll. Med. Mosul 2007; 33(1\&2) :26-34)

Received: $19^{\text {th }}$ Apr 2006; Accepted: $10^{\text {th }}$ Jul 2007

\begin{abstract}
Objectives 1.To detect the presence of chlamydia in the cervix of symptomatic and asymptomatic cases of cervicitis 2 . To conduct a full bacteriological identification of the microorganisms isolated from the cervix and vagina of the studied women 3 . To study the association between chlamydial infection and negative bacterial cultures. 4. To evaluate the findings of wet preparation of vaginal swabs in chlamydia positive and negative cases. 5. To estimate the serum concentration of C-reactive protein (CRP) in chlamydia positive and negative cases.
\end{abstract}

Materials and methods: This study was conducted during the period from December 2003 up to June 2004. It included a total of 200 women; 120 women were suffering from symptomatic cervicitis and 80 were asymptomatic for any gynaecological problems. Two endocervical and one high vaginal swabs were collected from each patient. One of the two endocervical swabs was used for the detection of chlamydia by immunochromatographic card test and the second one was used for bacterial culture. The high vaginal swab was used for wet preparation, and bacterial culture. The sera of these patients were tested for serum CRP level.

Results: Chlamydia infection was detected in $34(17 \%)$ of the total 200 cases studied. Among the symptomatic group, $19(15.9 \%)$ were found to be chlamydia positive, while among the asymptomatic group, $15(18.7 \%)$ were chlamydia positive. The association of chlamydia with negative bacterial culture was found to be significant in symptomatic group of patients $(p<$ $0.001)$, but not in the asymptomatic group ( $p>0.100$ ). The wet preparation findings in chlamydia positive cases revealed that the increased numbers of PMN ( $\geq 10 / \mathrm{hpf})$ were statistically not significant in symptomatic group ( $p>0.194)$, but significant in the asymptomatic group $(p<0.036)$. The association of chlamydia positivity with increased serum CRP level $(>6 \mathrm{mg} / \mathrm{L}$ ) was also found to be significant in both symptomatic and asymptomatic groups of cases $(p<0.001)$. Also, The presence of clue cells and Trichomonas vaginalis infection increases the possibility of chlamydia infection.

Conclusions: The immunochromatographic card test for chlamydia antigens represents a rapid, informative and not an expensive method for the detection of chlamydia infection. The negative bacterial cultures increase the possibility of chlamydia infection in symptomatic cases, but not in the asymptomatic ones. The CRP level increases significantly in infections caused by chlamydia, but not by other bacteria.

$$
\begin{aligned}
& \text { خلاصة البحث } \\
& \text { الأهداف: التحري عن وجود الحر اثف البر عميـة في عنق رحم النسـاء اللـواتي لديهن خمـج الجهاز التناسـلي }
\end{aligned}
$$

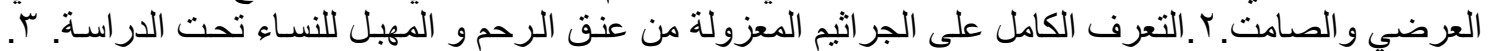

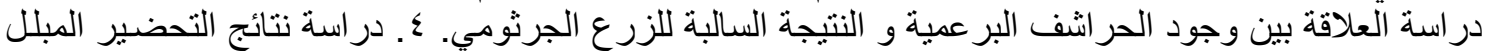

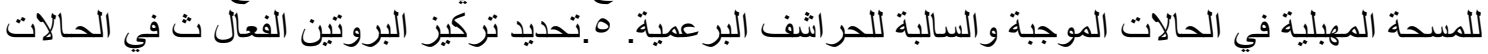

$$
\begin{aligned}
& \text { الموجبة والسالبة للحر اشف المئ البر عمية. }
\end{aligned}
$$

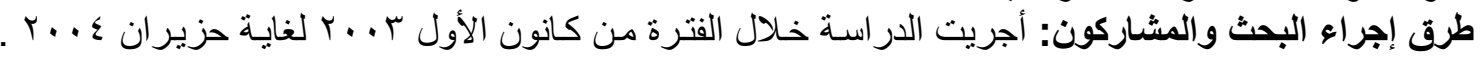

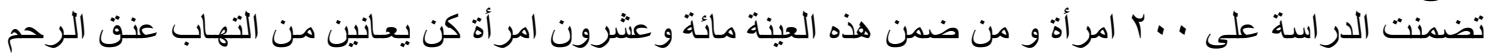

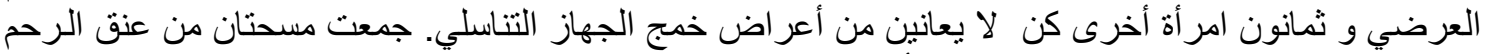

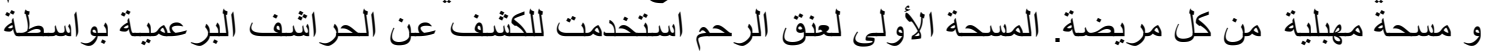

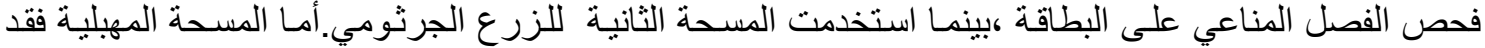

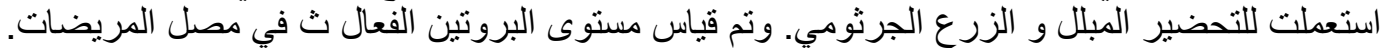

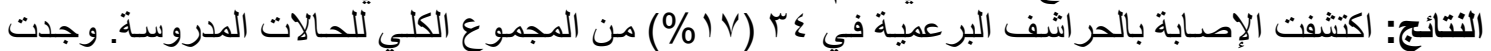

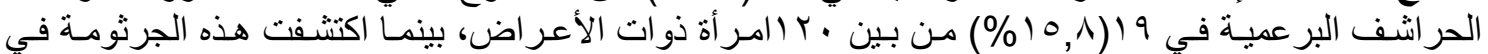




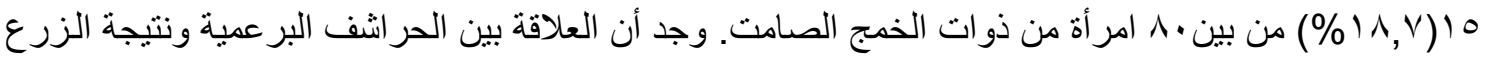

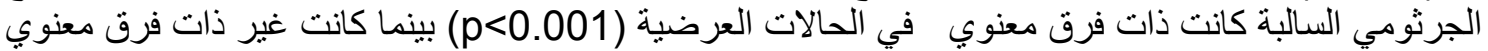

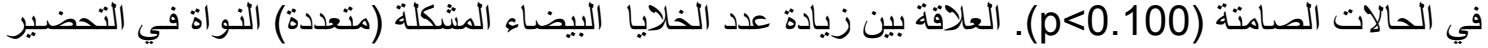

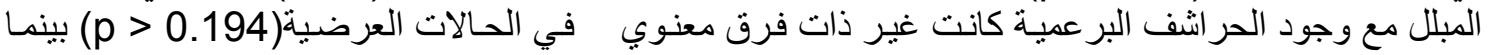

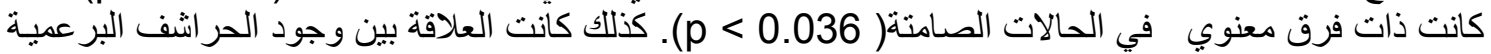

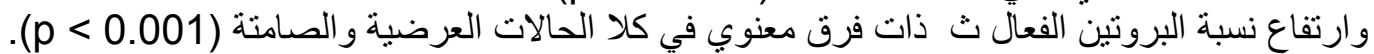

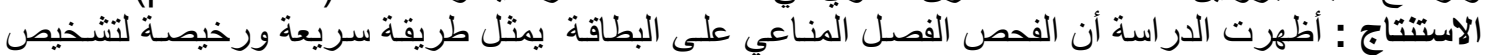

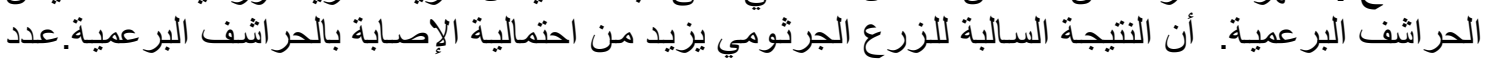

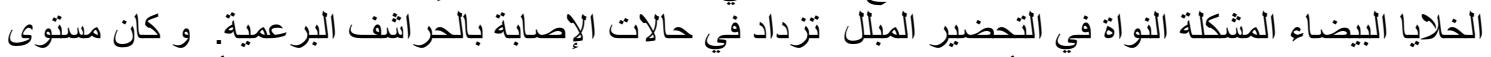

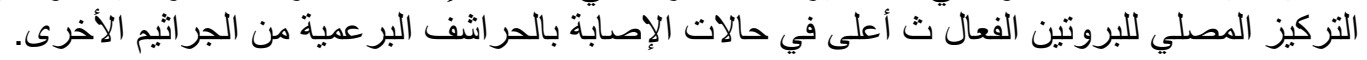

$\mathrm{M}$ ost women experience an infection of the genital tract at some time in their life. The sexually transmitted pathogens specially Chlamydia trachomatis and Neisseria gonorrhoeae infections cause a considerable morbidity in women. These infections remain asymptomatic and undetectable in a large proportion of females $^{(1,2)}$. The incidence of asymptomatic infections appears to be higher for Chlamydia trachomatis than Neisseria gonorrhoeae ${ }^{(3)}$.

Genital chlamydia infections (as other sexually transmitted diseases) affect mainly sexually active young adults ${ }^{(3,4)}$. They are recognized as the most prevalent and damaging sexually transmitted diseases. Chlamydia causes two main types of infections in females, which are mucopurulent cervicitis and pelvic inflammatory disease $(\mathrm{PID})^{(3,5)}$. The latter condition, accounts for the most serious acute illness with high morbidity in the infected women ${ }^{(6)}$. Chlamydial PID with salpingitis accounts for a large proportion of cases of tubal infertility and ectopic pregnancy as suggested by serological studies $^{(7)}$.

The other common infections in female genital tract are caused by groups of microorganisms, which include aerobic and anaerobic bacteria, Candida albicans, viruses and Trichomonas vaginalis ${ }^{(5,8)}$. These organisms can cause bacterial vaginosis and or pelvic infection, vulvovaginal candidiasis, viral cervicitis and vaginal trichomoniasis respectively. The vulvovaginal infections produce various combinations of vulvar irritation, dysuria, dyspareunia, and increased or altered vaginal discharge ${ }^{(5,8)}$. Certain vulvovaginal infections may have serious sequelae, as anaerobic PID and increased rate of sexual transmission of Human Immune Deficiency Virus ${ }^{(5,8)}$.

Finally, the genital tract infections are among the most frequent disorders for which patients seek care of gynaecologists.
Therefore, understanding the patho physiology of these diseases and having an effective approach to their diagnosis may enable physicians to institute an appropriate anti-microbial therapy to treat these conditions and reduce their long term sequelae.

Hence, the main aim of the present study is to explore the role of chlamydia and other bacteria as causes of cervicitis in the symptomatic and asymptomatic women.

\section{Patients and methods}

Two hundred women were enrolled in the present study. One hundred twenty women were suffering from symptomatic cervicitis and 80 were asymptomatic from any gynaecological problem. These patients attended the Outpatients Clinic in Al-Batool Maternity Teaching Hospital, Mosul.

\section{Specimens collection}

A. Swabs: A high vaginal and two cervical swabs were taken from all cases. Patients were examined by sterile specula under full-illuminated conditions. Using sterile cotton swabs the high vaginal samples were collected, but the two cervical swabs were taken from the endocervix which were collected by a special plastic shaft darcon swabs provided by the kit (see below). All samples were processed simultaneously according to the following steps:

1.The vaginal swab was used for wet preparation and bacterial culture.

2. One cervical swab was used for chlamydia detection by using rapid immunochromatographic card test (Acon ICH502, San Diego, USA).

3. The second cervical swab was used for bacterial culture.

The results of bacterial culture were interpreted as positive if there was growth of possible pathogenic bacteria, while negative results were reported if there was growth of normal flora (Lactobacilli or Diphetheroids) or no growth. 


\section{B. Blood samples}

Three milliliters $(\mathrm{ml})$ of venous blood were taken from all patients. The blood samples were collected in plain tubes and centrifuged for 10 minutes at 2500 RPM. The sera were separated and kept frozen at $-20 \mathrm{C}$ 。 until used for measurement of Creactive protein (CRP) level using latex agglutination slide test (Bicon, Germany).

\section{Results}

Detection of chlamydia: Using the rapid immunochromatographic card test (cassette) for chlamydia in the 200 symptomatic and asymptomatic cases studied, $34(17 \%)$ patients were found to be chlamydia positive. Nineteen $(15.9 \%)$ of the latter cases belong to the 120 symptomatic patients and $15(18.7 \%)$ cases belong to the 80 asymptomatic patients (Table 1). Therefore, the frequencies of chlamydia positivity among the positive symptomatic and asymptomatic cases were $55.9 \%$ and $44.1 \%$ respectively.

\section{Bacterial culture in relation to chlamydia}

\section{Chlamydia positive cases}

Among the 19 symptomatic chlamydia positive cases, $5(26.3 \%)$ patients had bacterial growth on ordinary culture media (culture positive) and $14(73.7 \%)$ revealed no growth (culture negative), (Table 2). These culture results were for both endocervical and vaginal swabs. The isolated microorganisms from the 2 types of swabs in the 5 culture positive cases were the same. Four out of these 5 patients had a single growth and the remaining one had mixed growths. The isolated bacteria in the chlamydia positive cases are shown in Table 4.

\section{Chlamydia negative cases}

The cervical and vaginal swabs among the 101 symptomatic chlamydia negative cases showed that $90(89.1 \%)$ were culture positive for other bacteria and 11 (10.9\%) were culture negative (Table 2). Among the culture positive cases, the growth was identified in $82(91.1 \%)$ patients, 6(6.7\%) cases from their cervical swabs and in the last $2(2.2 \%)$ patients from the vaginal swabs only. The cervical and vaginal swabs showed similar cultural results in $87 / 90$ $(96.7 \%)$ patients.
The total isolates of microorganisms from the 90 culture positive cases were 96 isolates. Single bacterial growths were seen among $84(93.3 \%)$ patients, while mixed growths were only seen in $6(6.7 \%)$ cases. The frequencies of isolated microorganisms are shown in Table 5. Among the 65 asymptomatic chlamydia negative cases, only $2(3.1 \%)$ were culture positive for both cervical and vaginal swabs (Table 3 ). The isolated microorganisms in these 2 cases were Klebsiella pneumoniae and $\beta$ haemolytic streptococci (Table 5).

The statistical association between chlamydia infection and negative bacterial culture in symptomatic cases was significant $(p<0.001)$, while it was not significant among the asymptomatic cases $(p>0.100)$.

\section{Wet preparation of vaginal swabs in relation to chlamydia}

The microscopical examination of wet preparation of the vaginal swabs was studied in both symptomatic and asymptomatic cases. These findings are shown in Table 6.

Among the 19 symptomatic chlamydia positive cases, the PMN (pus cells) counts of $<10 / \mathrm{hpf}$ were detected in $12(63.2 \%)$ cases and of $\geq 10 / \mathrm{hpf}$ were found in 7 $(36.8 \%)$ patients. The wet preparation findings also revealed that $3(15.8 \%)$ cases had clue cells and $16(84.2 \%)$ had no such cells. Furthermore, 2(10.5\%) cases were infected with Trichomonas vaginalis and the remaining 17 (89.5\%) patients were not. Candida budding cells were detected in 3 $(15.8 \%)$ cases, while the other $16(84.2 \%)$ patients had no such cells.

In the 15 asymptomatic chlamydia positive cases the PMN counts of $<10$ were detected in $10(66.7 \%)$ cases and of $\geq 10 /$ hpf were seen in $5(33.3 \%)$ patients. The wet preparation finding in these cases showed that $2(13.3 \%)$ patients had clue cells and $13(86.7 \%)$ cases had no such cells. Also, $1(6.7 \%)$ case only was infected with Trichomonas vaginalis and 14 (93.3\%) cases were not. Candida budding cells were detected in $2(13.3 \%)$ cases, while 13 $(86.7 \%)$ patients had no such finding.

The statistical association between symptomatic chlamydia positive cases and increased PMN counts ( $\geq 10 / \mathrm{hpf}$ ) in wet preparation of vaginal swabs in comparison with symptomatic chlamydia negative was 
found to be not significant ( $p>0.194)$. However, such an association among the asymptomatic chlamydia positive cases was statistically significant $(p<0.036)$.

\section{Serum c-reactive protein level}

The CRP level was evaluated in relation to the presence or absence of chlamydia in both symptomatic (Table, 7) and asymptomatic cases (Table, 8) chlamydia positive and negative cases.

The statistical association of CRP level $>6$ $\mathrm{mg} / \mathrm{L}$ in chlamydia positive cases was significantly higher $(p<0.001)$ than chlamydia negative cases of both symptomatic and asymptomatic types.

Table 1: Numbers and percentages of chlamydia infection detected in symptomatic and asymptomatic cases.

\begin{tabular}{|c|c|c|c|}
\hline \multirow{2}{*}{ Patients } & \multicolumn{2}{|c|}{ No. (\%) } & \multirow{2}{*}{ Total } \\
\cline { 2 - 3 } & Chlamydia positive & Chlamydia negative & \\
\hline Symptomatic & $19(15.83)$ & $101(84.17)$ & 120 \\
\hline Asymptomatic & $15(18.7)$ & $65(81.25)$ & 80 \\
\hline Total & $34(17)$ & $166(83)$ & $200(100)$ \\
\hline
\end{tabular}

Table 2: Presence of chlamydia according to the bacterial growth in symptomatic cases.

\begin{tabular}{|c|c|c|c|}
\hline \multirow{2}{*}{ Bacterial culture } & \multicolumn{2}{|c|}{ No. (\%) } & \multirow{2}{*}{ p-value } \\
\cline { 2 - 3 } & Chlamydia positive & Chlamydia negative & \\
\hline Positive & $5(26.3)$ & $90(89.2)$ & \multirow{2}{*}{$0.001>$} \\
\hline Negative & $14(73.3)$ & $11(10.8)$ & \\
\hline Total & $19(100)$ & $101(100)$ & \\
\hline
\end{tabular}

Table 3: Presence of Chlamvdia accordina to the bacterial arowth in asvmotomatic cases.

\begin{tabular}{|c|c|c|c|}
\hline \multirow{2}{*}{ Bacterial culture } & \multicolumn{2}{|c|}{ No. (\%) } & \multirow{2}{*}{ p-value } \\
\cline { 2 - 3 } & Chlamydia positive & Chlamydia negative & \\
\hline Positive & $2(13.3)$ & $2(1.1)$ & \\
\hline Negative & $13(86.7)$ & $63(98.9)$ & $<01 \ldots$ \\
\hline Total & $15(100)$ & $65(100)$ & $<$ \\
\hline
\end{tabular}


Table 4: The isolated bacteria and their percentages in chlamydia positive cases.

\begin{tabular}{|c|c|c|c|c|c|c|}
\hline \multirow[b]{3}{*}{ Type of isolates } & \multicolumn{3}{|c|}{$\begin{array}{c}\text { Symptomatic } \\
\text { (culture positive) } \\
\text { No.=5 }\end{array}$} & \multicolumn{3}{|c|}{$\begin{array}{c}\text { Asymptomatic } \\
\text { (culture positive) } \\
\text { No.=2 }\end{array}$} \\
\hline & \multirow[b]{2}{*}{$\begin{array}{c}\text { Bacterial } \\
\text { No. }\end{array}$} & \multicolumn{2}{|c|}{$\%$} & \multirow[b]{2}{*}{$\begin{array}{c}\text { Bacterial } \\
\text { No. }\end{array}$} & \multicolumn{2}{|c|}{$\%$} \\
\hline & & $\begin{array}{c}\text { From } \\
\text { isolates }\end{array}$ & $\begin{array}{l}\text { From } \\
\text { cases }\end{array}$ & & $\begin{array}{c}\text { From } \\
\text { isolates }\end{array}$ & $\begin{array}{l}\text { From } \\
\text { cases }\end{array}$ \\
\hline & 3 & 50 & 60 & 0 & 0 & 0 \\
\hline Enterobacter & & & & & & \\
\hline E.coli & 1 & $16.7^{*}$ & 20 & 1 & 50 & 50 \\
\hline Enterococcus feacalis & 1 & 16.7 & 20 & 0 & $\mathbf{0}$ & 0 \\
\hline Pseudomonas aeruginosa & 1 & $16.7^{*}$ & 20 & $\mathbf{0}$ & $\mathbf{0}$ & $\mathbf{0}$ \\
\hline Proteus mirabilis & $\mathbf{0}$ & 0 & 0 & 1 & 50 & 50 \\
\hline
\end{tabular}

Table 5: The isolated bacteria and their percentages in Chlamydia negative cases.

\begin{tabular}{|c|c|c|c|c|c|c|}
\hline \multirow{4}{*}{ Type of isolates } & \multicolumn{6}{|c|}{ Chlamydia negative } \\
\hline & \multicolumn{3}{|c|}{ Symptomatic } & \multicolumn{3}{|c|}{ Asymptomatic } \\
\hline & \multirow[b]{2}{*}{$\begin{array}{c}\text { No. of } \\
\text { isolates }\end{array}$} & \multicolumn{2}{|c|}{$\%$} & \multirow[b]{2}{*}{$\begin{array}{c}\text { No. of } \\
\text { isolates }\end{array}$} & \multicolumn{2}{|c|}{$\%$} \\
\hline & & $\begin{array}{c}\text { From } \\
\text { isolates } \\
\text { No. }=96\end{array}$ & $\begin{array}{c}\begin{array}{c}\text { From } \\
\text { cases } \\
\text { No. }=101\end{array} \\
\end{array}$ & & $\begin{array}{c}\text { From } \\
\text { isolates } \\
\text { No. }=2\end{array}$ & $\begin{array}{c}\text { From } \\
\text { cases } \\
\text { No. }=65\end{array}$ \\
\hline E.coli & 30 & 31.3 & 33.3 & 0 & 0 & 0 \\
\hline Enterobacter & 10 & 10.4 & 11.1 & 0 & 0 & $\mathbf{0}$ \\
\hline Klebsiella pneumoniae & 10 & 10.4 & 11.1 & 1 & 50 & 1.5 \\
\hline Non-hemolytic streptococcus & 9 & 9.4 & 10 & 0 & 0 & 0 \\
\hline Gardnerlla vaginalis & 8 & 8.3 & 8.9 & 0 & 0 & 0 \\
\hline Staphylococcus aureus & 5 & 5.2 & 5.6 & 0 & 0 & 0 \\
\hline Proteus mirabilis & 4 & 4.2 & 4.4 & 0 & 0 & 0 \\
\hline â-hemolytic streptococcus & 4 & 4.2 & 4.4 & 1 & 50 & 1.5 \\
\hline â-hemolytic streptococcus & 3 & 3.1 & 3.3 & 0 & 0 & 0 \\
\hline Peptostreptococcus & 3 & 3.1 & 3.3 & 0 & 0 & 0 \\
\hline Aeromonas & 3 & 3.1 & 3.3 & 0 & 0 & 0 \\
\hline Citerobacter & 2 & 2.1 & 2.2 & 0 & 0 & 0 \\
\hline Neisseria gonorrhoea & 1 & 1 & 1.1 & 0 & 0 & 0 \\
\hline Alcaligenes & 1 & 1 & 1.1 & 0 & 0 & 0 \\
\hline Plesimonas & 1 & 1 & 1.1 & 0 & 0 & 0 \\
\hline Mobiluncus & 1 & 1 & 1.1 & 0 & 0 & 0 \\
\hline Enterococcus faecalis & 1 & 1 & 1.1 & $\mathbf{0}$ & $\begin{array}{ll}0 & \\
\end{array}$ & $\mathbf{0}$ \\
\hline
\end{tabular}


Table 6: Microscopical findings of wet preparations in symptomatic and asymptomatic chlamydia positive and negative cases.

\begin{tabular}{|c|c|c|c|c|}
\hline \multirow{3}{*}{$\begin{array}{l}\text { Wet preparation } \\
\text { items }\end{array}$} & \multicolumn{4}{|c|}{ No. (\%) } \\
\hline & \multicolumn{2}{|c|}{ Chlamydia positive } & \multicolumn{2}{|c|}{ Chlamydia negative } \\
\hline & $\begin{array}{c}\text { Symptomatic } \\
\text { No. }=19\end{array}$ & $\begin{array}{c}\text { Asymptomatic } \\
\text { No. }=15\end{array}$ & $\begin{array}{c}\text { Symptomatic } \\
\text { No. }=101\end{array}$ & $\begin{array}{c}\text { Asymptomatic } \\
\text { No. }=65\end{array}$ \\
\hline $\begin{array}{l}P M N \\
<10 \\
\geq 10\end{array}$ & $\begin{array}{c}12(63.2) \\
7(36.8)\end{array}$ & $\begin{array}{c}10(66.7) \\
5(33.3)\end{array}$ & $\begin{array}{l}78(77.6) \\
23(22.7)\end{array}$ & $\begin{array}{c}59(90.7) \\
6(9.3)\end{array}$ \\
\hline $\begin{array}{l}\text { Clue cells } \\
\text { Positive } \\
\text { negative }\end{array}$ & $\begin{array}{c}3(15.8) \\
16(84.2)\end{array}$ & $\begin{array}{c}2(13.3) \\
13(86.7)\end{array}$ & $\begin{array}{c}10(9.9) \\
91(90.1)\end{array}$ & $\begin{array}{c}2(3.1) \\
63(96.9)\end{array}$ \\
\hline $\begin{array}{l}\text { Trichomonas } \\
\text { positive } \\
\text { negative }\end{array}$ & $\begin{array}{c}2(10.5) \\
17(89.5)\end{array}$ & $\begin{array}{c}1(6.7) \\
14(93.3)\end{array}$ & $\begin{array}{c}8(7.9) \\
93(92.1)\end{array}$ & $\begin{array}{c}1(1.5) \\
64(98.5)\end{array}$ \\
\hline $\begin{array}{l}\text { Candida } \\
\text { Positive } \\
\text { negative }\end{array}$ & $\begin{array}{c}3(15.8) \\
16(84.2)\end{array}$ & $\begin{array}{c}2(13.3) \\
13(86.7)\end{array}$ & $\begin{array}{l}20(19.9) \\
81(80.1)\end{array}$ & $\begin{array}{c}3(4.6) \\
62(95.4)\end{array}$ \\
\hline
\end{tabular}

Table 7: The CRP level in symptomatic chlamydia positive and negative cases.

\begin{tabular}{|c|c|c|c|c|c|c|c|}
\hline \multirow{4}{*}{ Symptomatic cases } & \multicolumn{6}{|c|}{ No. (\%) } & \multirow{4}{*}{$p$ - value } \\
\hline & & & CRP lev & $\mathrm{ng} / \mathrm{L})$ & & & \\
\hline & \multirow[t]{2}{*}{$\geq 6$} & \multicolumn{5}{|c|}{$<6$} & \\
\hline & & 12 & 18 & 24 & 36 & Total & \\
\hline Chlamydia positive & $\begin{array}{c}3 \\
(15.8)\end{array}$ & $\begin{array}{c}8 \\
(50)\end{array}$ & $\begin{array}{c}3 \\
(18.8)\end{array}$ & $\begin{array}{c}4 \\
(25)\end{array}$ & $\begin{array}{c}1 \\
(7.2)\end{array}$ & 16 & \multirow{3}{*}{$0.001>$} \\
\hline Chlamydia negative & $\begin{array}{c}82 \\
(81.2)\end{array}$ & $\begin{array}{c}8 \\
(42.1)\end{array}$ & $\begin{array}{c}2 \\
(10.5)\end{array}$ & $\begin{array}{c}7 \\
(36.8)\end{array}$ & $\begin{array}{c}2 \\
(10.5)\end{array}$ & 19 & \\
\hline Total & 85 & $\begin{array}{c}16 \\
(45.7)\end{array}$ & $\begin{array}{c}5 \\
(14.3)\end{array}$ & $\begin{array}{c}11 \\
(31.4)\end{array}$ & $\begin{array}{c}3 \\
(8.6)\end{array}$ & 35 & \\
\hline
\end{tabular}

Table 8: The CRP level in asymptomatic chlamydia positive and negative cases.

\begin{tabular}{|c|c|c|c|c|c|c|c|}
\hline \multirow{4}{*}{ Asymptomatic cases } & \multicolumn{6}{|c|}{ No. (\%) } & \multirow{4}{*}{$p$-value } \\
\hline & & & RP leve & ng/L) & & & \\
\hline & \multirow[t]{2}{*}{$\geq 6$} & \multicolumn{5}{|c|}{$<6$} & \\
\hline & & 12 & 18 & 24 & 36 & Total & \\
\hline Chlamydia positive & $\begin{array}{c}4 \\
(26.7)\end{array}$ & $\begin{array}{c}6 \\
(54.5)\end{array}$ & $\begin{array}{c}2 \\
(18.2)\end{array}$ & $\begin{array}{c}2 \\
(18.2)\end{array}$ & $\begin{array}{c}1 \\
(9.1)\end{array}$ & 11 & \\
\hline Chlamydia negative & $\begin{array}{c}61 \\
(93.9)\end{array}$ & $\begin{array}{c}4 \\
(100)\end{array}$ & $\begin{array}{c}0 \\
(0)\end{array}$ & $\begin{array}{c}0 \\
(0)\end{array}$ & $\begin{array}{c}0 \\
(0)\end{array}$ & 4 & \\
\hline Total & 65 & $\begin{array}{c}10 \\
(66.7)\end{array}$ & $\begin{array}{c}2 \\
(13.3)\end{array}$ & $\begin{array}{c}2 \\
(13.3)\end{array}$ & $\begin{array}{c}1 \\
(6.7)\end{array}$ & 15 & \\
\hline
\end{tabular}




\section{Discussion}

Generally, the diagnosis of chlamydia is not easy due to the difficulties in its culturing and its direct identification using special staining techniques ${ }^{(6)}$. Consequently, patients with chlamydia infection may suffer from long term sequelae, e.g., PID. Recently, immunochromatographic card test was developed for the detection of chlamydial antigen and was used in the present study. It provided a rapid and practical way for the detection of chlamydial infection.

In the current study, the prevalence of chlamydia in symptomatic and asymptomatic cases was $15.9 \%$ and $18.7 \%$ respectively. Previous studies reported a wide range of discrepancies in the prevalence of chlamydia in both groups of such patients. The prevalence of chlamydia in symptomatic cases in those reports was $3.4-44 \%{ }^{(9,10)}$, while in the asymptomatic groups it ranged from $5-14.5 \%^{(9,11)}$. These differences in the prevalence of chlamydia between the various studies could be attributed to geographical, social variation, or to the type of tests used for the detection of chlamydia.

The coexistence of chlamydia with other pathogenic or opportunistic microorganisms is an important issue, which has to be investigated. In the current work the association between chlamydia infection and negative bacterial culture had been studied. This association was found to be statistically significant in symptomatic cases $(p<0.001)$, but not in the asymptomatic cases $(p>0.100)$. However, culture positivity for bacteria in both symptomatic and asymptomatic patients did not exclude the possibility of chlamydia infection in spite of being not significant. This significant association may be explained on the basis that the symptoms in the culture negative cases were mainly due to chlamydial infection, while those of culture positive cases were caused mainly $(89.1 \%)$ by nonchlamydial bacterial infections. In the asymptomatic cases the association was not significant because the majority $(96.9 \%)$ of patients did not have bacterial growth. The presence of bacterial cervicitis decreased the possibility of encountering chlamydia from 14/19 in culture negative cases to $5 / 19$ in culture positive cases. These results could be attributed to the presence of other bacteria in the cervix which might affect the colonization of the area by chlamydia. The production of lactic acid, bacterial toxin or enzymes by nonchlamydial microorganisms might cause such an effect.

The cultures in symptomatic chlamydia negative cases showed bacterial growth in $89.1 \%$ of the cases. Cervical and vaginal swabs had similar isolates in $96.7 \%$ of the cases. A Single bacterial growth was identified in $93.3 \%$ of cases.

The findings of wet preparation were evaluated in accordance to the presence of chlamydia. The association of chlamydia with increased PMN counts ( $>10 / \mathrm{hpf}$ ) in both symptomatic and asymptomatic chlamydia positive cases was studied. Among the symptomatic chlamydia positive cases, this association was statistically not significant $\quad(p>0.194)$. This result is consistent with some previous works $(12,13)$ and contradicts with others $(14,15)$. In the asymptomatic chlamydia positive cases, the association of chlamydia with increased PMN counts was statistically significant $(p<0.036)$. This finding is in keeping with that of Hakakha and coworkers (15). The difference in the association of the presence of the chlamydia with increased PMN counts in symptomatic and asymptomatic cases might be due to the non chlamydial bacterial infection in the former than in the latter group that could increase the PMN counts.

The wet preparation findings in symptomatic and asymptomatic chlamydia positive cases showed the presence of clue cells in $15.3 \%$ and $13.3 \%$ of cases respectively. Majeroni and colleagues Hakakha and coworkers $(13,15)$ reported comparable findings. Candida budding cells in wet preparation of chlamydia positive cases were detected in $15.3 \%$ of symptomatic patients and $13.3 \%$ of asymptomatic cases. Similar findings were reported by Moller and coworker (1985) (9).

The co-infection of chlamydia with Trichomonas vaginalis was found in $10.5 \%$ of symptomatic patients and in $6.7 \%$ of asymptomatic ones. A previous work of Garland (16) had demonstrated such a coexistence of infections. Among the chlamydia negative cases, Trichomonas vaginalis was found in $7.9 \%$ of symptomatic cases, while in the 
asymptomatic it was detected in $1.5 \%$ of patients. These results suggest that Trichomonal infection increases the possibility of chlamydial infection in both symptomatic and asymptomatic patients.

The CRP is usually elevated in response to systemic inflammatory process ${ }^{(17)}$. The association between chlamydia and increased CRP level (>6 mg/L) was studied in both symptomatic and asymptomatic cases. A significant association was found in both groups of cases $(p<0.001)$. One previous study conducted by Schalla and colleagues $^{(18)}$ showed that the CRP level increased in the complicated cases of chlamydia. Also, this study showed that there was no statistical association between uncomplicated chlamydia and increasing CRP level. Therefore, the significant association between these two parameters in the present study may be due to the fact that PID complicated most cases of chlamydia. Interestingly, it was found that the lower genital tract infection (cervicitis and vaginitis) caused by bacteria other than chlamydia did not show an increase in the CRP level.

\section{In Conclusion}

the immunochromatographic card test for chlamydia antigen represents a rapid, informative and not an expensive method for the detection of chlamydia infection. The negative bacterial cultures increase the possibility of chlamydia infection in symptomatic cases, but not in the asymptomatic ones. The presence of clue cells and Trichomonal infection increases the possibility of chlamydia infection. The CRP level increases significantly in infection caused by chlamydia, but not other bacteria.

\section{References}

1. Campbell $S$ and Monga $A$ Infections in gynaecology. Gynaecology by Ten Teachers, $17^{\text {th }}$ ed, Oxford University Press Inc, New York; (2000). 183-204.

2. Myziuk L, Romanowsk $B$ and Brow M. Endocervical gram's stain and their usefulness in the diagnosis of Chlamydia trachomatis. Sex Trans Inf; (2001) 77: 103-106.

3. Estam $M$ Chlamydia infection. In Braanwald E, Fauci AS Kasper DL et al. Harrison of Internal Medicine $15^{\text {th }}$ ed, New York; Mc (1998). 1075-1082.

4. Braverman $P K$ Sexually transmitted disease in adolescents. Medical Clinic of North America; (2000). 84: 869-889.

5. Kimberly AW and William CL Sexually transmitted disease treatment guideline CDC, MMWR; 2002. 51 /RR-6: 1-78.

6. Berman SM, Campbell $\mathrm{CH}$, Geissman $\mathrm{K}$ et al. Recommendation for prevention and management of Chlamydia trachomatis infections. CDC, MMWR; (1993). 142/ RR-12: 1-32.

7. Hicks NR, Dawes M, Hamling $J$ et al . Chlamydia infections in general practice. Br Med J;(1999). 318: 790792.

8. Holmes KK Pelvic inflammatory disease, Lower genital infection. In Braanwald E, Fauci AS Kasper DL et al. Harrison of Internal Medicine $15^{\text {th }}$ ed, New York Mc Graw Hill (1998). 839853.

9. Moller BR, Jorgensen A, From E et al. Chlamydia, Mycoplasma, Ureaplasma and Yeast in lower tract comparison between a group attending Venereal Disease Clinic and a control group. Act Obstet Gynecol Scand; (1985). 64: 145149.

10. Gibney L, Mascaluso M, Kirk K et al . Prevalence of infectious disease in Bangladesh women living adjacent to a trunk stands HIV/STD/Hepatitis/GTI. Sex Trans inf; ( $r . .1$ ) 77:344-350.

11. Mertz KJ, Ransom RL, Louis ME et al . Prevalence of genital chlamydial infection in young women entering a National Job Training Program 19901997. Am J of Public Health; $(Y \ldots)$ ). 91: 1287-1293.

12. Thejls $H$, Rahm VA, Rosen $G$ et al. Corelation between chlamydia infection and clinical evaluation, vaginal wet smear and cervical swab test in female adolescents. Am J Obstet Gynecol; (1987). 157: 974-976.

13. Majeroni BA, Schank JN, Horwitz M et alUse of wet mount to predict Chlamydia trachomatis and Neisseria gonorrhoea cervicitis in primary care. Fam Med; (1996). 7818:580-583.

14. Steinhardler L, Perpert J, Heber W et al Combination of bacterial vaginosis and leukorrhoea as a predictor of cervical chlamydial or gonococcal infection. Obstet Gynaecol; (2002). 99:603-607. 
15. Hakakha MM, Davis J, Korst LM et al. Leukorrheoa and bacterial vaginosis as in office predictors of cervical infection in high-risk women. Obstet Gynaecol; (2002). 100: 808-812.

16. Garland SM, Tabrizi SN, Chen S et al. Prevalence of sexually transmitted infections (Neisseria gonorrhoea, Chlamydia trachomatis, Trichomonas vaginalis and human papilloma virus) in female attendees of sexually transmitted diseases in Clinic in
Ulaanbaatar, Mongolia. Infect Dis Obstet Gynecol; (2001). 9: 143-146.

17. Pepys MB and Hirschfield GM Creactive protein a critical update. J Clin Invest; (2003). 111:1805-1812.

18. Schalla WO Arko RJ and Thopson SE Evalution of C-reactive protein latex agglutination detection test with sera from patients with sexually transmitted disease. J Clin Microb; (1984). 20: 1171-1173. 